\title{
Microbiological profile of leg ulcer infections: review study
}

\author{
Perfil microbiológico das infecções de úlceras de perna: estudo de revisão \\ Perfil microbiológico de las infecciones de ulceras de pierna: estudio de revisión
}

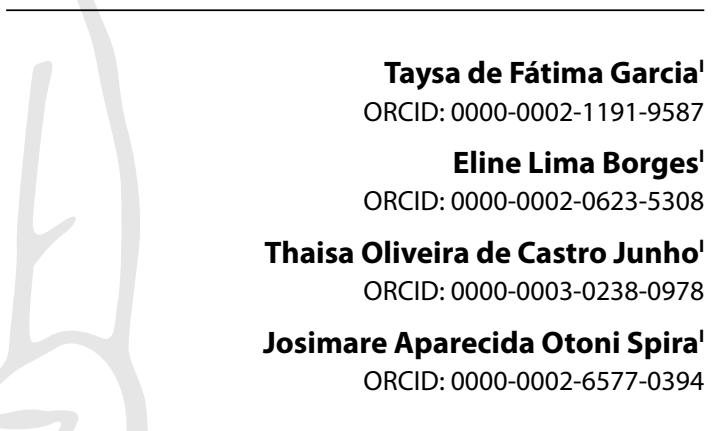

'Universidade Federal de Minas Gerais. Belo Horizonte, Minas Gerais, Brazil.

How to cite this article: Garcia TF, Borges EL, Junho TOC, Spira JAO. Microbiological profile of leg ulcer infections: review study. Rev Bras Enferm. 2021;74(3):e20190763. https://doi.org/10.1590/0034-7167-2019-0763

Corresponding author:

Taysa de Fátima Garcia

E-mail: taysafati@hotmail.com

EDITOR IN CHIEF: Dulce Barbosa ASSOCIATE EDITOR: Marcos Brandão

Submission: 01-17-2020

Approval: 01-09-2021

\begin{abstract}
Objectives: to analyze the microbiological profile of leg ulcers of patients treated at outpatient clinics and hospitals regarding the type of microorganism, microbiological selection of antibiotics, and techniques for the collection of culture material. Methods: literature review performed on LILACS, IBECS, MEDLINE, and CINAHL databases, resulting in a descriptive analysis of 27 studies. Results: $35.7 \%$ of the studies occurred in an outpatient care scenario; and $64.2 \%$ in hospitals. There was a predominance of swab (100\%) in outpatient care and biopsy (55.5\%) in the hospital. Escherichia coli, Pseudomonas aeruginosa, and Staphylococcus aureus were more common at both levels of assistance. Methicillin-resistant Staphylococcus aureus was isolated in both. Conclusions: the microbiological profile of infections was similar, with the presence of resistant bacteria in both environments. This fact causes concern and raises the need for research to elucidate it. The studies did not compare the effectiveness between biopsy and swab. Descriptors: Leg Ulcer; Culture Techniques; Bacterial Growth; Infection; Nursing.
\end{abstract}

\section{RESUMO}

Objetivos: analisar o perfil microbiológico de úlceras de perna de pacientes atendidos em ambulatório e hospital quanto ao tipo de microrganismo, seleção microbiológica aos antibióticos e técnicas de coleta de material para cultura. Métodos: revisão da literatura realizada nas bases LILACS, IBECS, MEDLINE e CINAHL, resultando em 27 estudos analisados descritivamente. Resultados: ocorreram em ambulatório, 35,7\% dos estudos; e em hospitais, $64,2 \%$. Predominaram swab (100\%) em ambulatório e biópsia (55,5\%) no hospital. Escherichia coli, Pseudomonas aeruginosa e o Staphylococcus aureus foram mais comuns nos dois níveis de assistência. Houve o isolamento de Staphylococcus aureus resistente à meticilina em ambos. Conclusões: o perfil microbiológico das infecções foi semelhante, com presença de bactérias resistentes nos dois ambientes. Esse fato causa preocupação e suscita necessidade de pesquisas para elucidá-lo. Os estudos não compararam a efetividade entre biópsia e swab.

Descritores: Úlcera de Perna; Técnicas de Cultura; Crescimento Bacteriano; Infecção; Enfermagem.

\section{RESUMEN}

Objetivos: analizar perfil microbiológico de úlceras de pierna de pacientes atendidos en ambulatorio y hospital cuanto al tipo de microorganismo, selección microbiológica a los antibióticos y técnicas de recogida de material para cultura. Métodos: revisión de literatura realizada en bases LILACS, IBECS, MEDLINE y CINAHL, resultando en 27 estudios analizados descriptivamente. Resultados: ocurrieron en ambulatorio, 35,7\% de los estudios; $y$ en hospitales, $64,2 \%$. Predominaron swab (100\%) en ambulatorio y biopsia (55,5\%) en hospital. Escherichia coli, Pseudomonas aeruginosa y Staphylococcus aureus fueron más comunes en dos niveles de asistencia. Hubo el aislamiento de Staphylococcus aureus resistente a la meticilina en ambos. Conclusiones: perfil microbiológico de las infecciones fue semejante, con presencia de bacterias resistentes en los dos ambientes. Ese hecho causa preocupación y suscita necesidad de investigaciones para elucidarlo. Estudios no compararon la efectividad entre biopsia y swab. Descriptores: Ulcera de la Pierna; Técnicas de Cultivo; Crecimiento Bacteriano; Infección; Enfermería. 


\section{INTRODUCTION}

Leg ulcer is defined as a skin defect below knee level that persists for more than six weeks and shows no tendency of healing after three or more months, and is part of the group of chronic wounds. This condition is not considered a medical diagnosis, but a manifestation of the disease process. It is a relatively common condition among adults, affecting $1 \%$ of the adult population and $3.6 \%$ of people over 65 years of age. Common causes are venous and arterial diseases, and neuropathy. The causes which are less common are ones related to metabolic and hematological disorders, and infectious diseases ${ }^{(1)}$. Most patients with chronic wounds will be treated by several professionals in Primary Care (community). Also, its occurrence imposes a substantial economic burden on health care: for example, 5 billion pounds in the United Kingdom, where there are approximately 2.2 million patients with wounds, which makes up $4.5 \%$ of the adult population ${ }^{(2)}$.

Most ulcers cannot be cured in a short period of time. These aspects can be aggravated in the occurrence of an infection, as it results in an increase in the ulcer's healing period and often leads to hospitalization which generates a higher cost of care and treatment, including surgical interventions ${ }^{(3)}$ and eventually prolongs the patient's hospitalization. Infections in leg ulcers can be caused by Gram-positive and Gram-negative bacteria. Among the most frequent bacteria are Staphylococcus aureus, Pseudomonas aeruginosa, Enterococcus faecalis, Klebsiella pneumoniae, and Escherichia coli $^{(4-5)}$. These bacteria, although common, can represent a major challenge for therapy when they develop resistance to one or more antibiotics.

The diagnosis of local infection of the wound bed is considered a clinical decision, according to clear criteria of symptoms, a holistic assessment of the patient, and its occurrence requires the timely implementation of appropriate treatment ${ }^{(6)}$. Early recognition, along with the appropriate and effective immediate intervention, is considered essential in the optimization of patient results, maximizing the management of resources in Primary Care ${ }^{(7)}$. In the care environment for patients with leg ulcers, the occurrence of an infection and its treatment demand careful attention from professionals, given the absence of specific protocols for the collection of culture material and the proposal for treatment with topical antimicrobials and systemic antibiotics in the majority of health institutions. This context is a challenging issue in clinical practice, since formal guidelines should support professionals in the constructive implementation of clinical diagnosis tools in order to provide an economic and effective service ${ }^{(7)}$.

Although health professionals in clinical practice identify leg ulcer infection as a complication, this is still a topic that requires investigation to produce answers that help nurses with the assessment, conduct, and microbiological profile in different health services and countries.

\section{OBJECTIVES}

To analyze the bacteriological profile of leg ulcers of patients cared for in outpatient and hospital units regarding the type of microorganism and microbiological selection in relation to antibiotics; and techniques for collecting culture material.

\section{METHODS}

Integrative literature review, which aims to synthesize and gather scientific evidence through the analysis of multiple studies on a given topic, contributing to critical analysis of professionals in order to support new reflections and respond to knowledge gaps, supporting decision making ${ }^{(8)}$. The research question, conceived according to the P.I.C.O. strategy, was thus determined: What is the bacteriological profile of leg ulcer infections and the techniques used to collect material for culture?

The inclusion criteria were: studies that necessarily addressed the bacteriological profile of infection in leg ulcers of any etiology, including the diabetic foot or the technique of collecting material from these ulcers for culture; in patients 18 years of age or older, regardless of gender; assisted in Primary Care, outpatient, and hospital level; original studies, available in full, published between 2008 and 2020. The exclusion criteria adopted were: ongoing studies and research protocols; articles that addressed colonization or treatment; studies that dealt with the prevention or cause of these injuries, reports or case studies, specialist consensus.

The search in the electronic databases took place in two phases: the first, between December 2018 and January 2019; and the second, in June 2020. It was carried out by two independent reviewers. The following databases were consulted: Literatura Latino-Americana e do Caribe em Ciências da Saúde (LILACS) [Latin American and Caribbean Health Sciences Literature], Índice Bibliográfico Espanhol de Ciências da Saúde (IBECS) [Spanish Bibliographic Index of Health Sciences], Centro Nacional de Informação de Ciências Médicas de Cuba (CUMED) [National Center for Medical Sciences Information in Cuba], Medical Literature Analysis and Retrieval System Online (MEDLINE), The United Kingdom Cochrane Library Collaboration (COCHRANE), Cumulative Index to Nursing and Allied Health Literature (CINAHL).

Controlled descriptors were used, according to the nomenclature of Descritores em Ciências da Saúde (DeCS) [Health Sciences Descriptors] of the Biblioteca Virtual em Saúde (BVS) [Virtual Health Library], and Medical Subject Headings (MeSH) of the United States National Library of Medicine (US NLM), in the English, Portuguese, and Spanish languages: Leg Ulcer, Foot Ulcer, Varicose Ulcer, Infection, Wound Infection, Infection Control, Staphylococcal Infections, Pseudomonas Infections, Bacterial Growth, Bacterial Growth Phases, Bacteria, Anaerobic Bacteria, Aerobic Gram-Negative Bacteria, GramPositive Bacteria, Streptococcus pyogenes. Crossings were performed between the descriptors using the support of the Boolean operators AND and OR in all databases in order to refine the search for studies.

The main search strategy was carried out in the Medline database via PubMed: ((()(()("Bacteria"[Mesh]) OR "Bacteria, Anaerobic"[Mesh]) OR "Bacteria, Aerobic"[Mesh]) OR "Gram-Negative Bacteria"[Mesh]) OR "Gram-Positive Bacteria"[Mesh]) OR "Streptococcus pyogenes"[Mesh])) OR ("Bacteria"[Title/Abstract] OR "Bacteria, Anaerobic"[Title/Abstract] OR "Bacteria, Aerobic"[Title/Abstract] OR "Gram-Negative Bacteria"[Title/Abstract]OR "GramPositive Bacteria"[Title/Abstract]OR "Streptococcus pyogenes"[Title/Abstract] OR "Bacterial Growth"[Title/ Abstract]))) AND (((((("Infection"[Mesh]) OR "Wound Infection"[Mesh]) OR "Infection Control"[Mesh]) OR "Staphylococcal Infections"[Mesh]) OR "Pseudomonas Infections"[Mesh])) OR ("Infection"[Title/Abstract] OR "Wound Infection"[Title/Abstract] OR "Infection Control"[Title/Abstract]OR "Staphylococcal Infections"[Title/Abstract] OR "Pseudomonas 
Infections"[Title/Abstract]))) AND ((((("Leg Ulcer"[Mesh]) OR "Foot Ulcer"[Mesh]) OR "Varicose Ulcer"[Mesh])) OR ("Leg Ulcer"[Title/ Abstract] OR "Foot Ulcer"[Title/Abstract] OR "Varicose Ulcer"[Title/ Abstract])). At the end, 397 articles were identified. In the databases of CINAHL and Cochrane via the CAPES Portal as well as LILACS; for IBECS and CUMED via the BVS, similar strategies were used and found, respectively, 79 and 31 articles, reaching a total of 507. The flowchart of studies selection is shown in Figure 1.

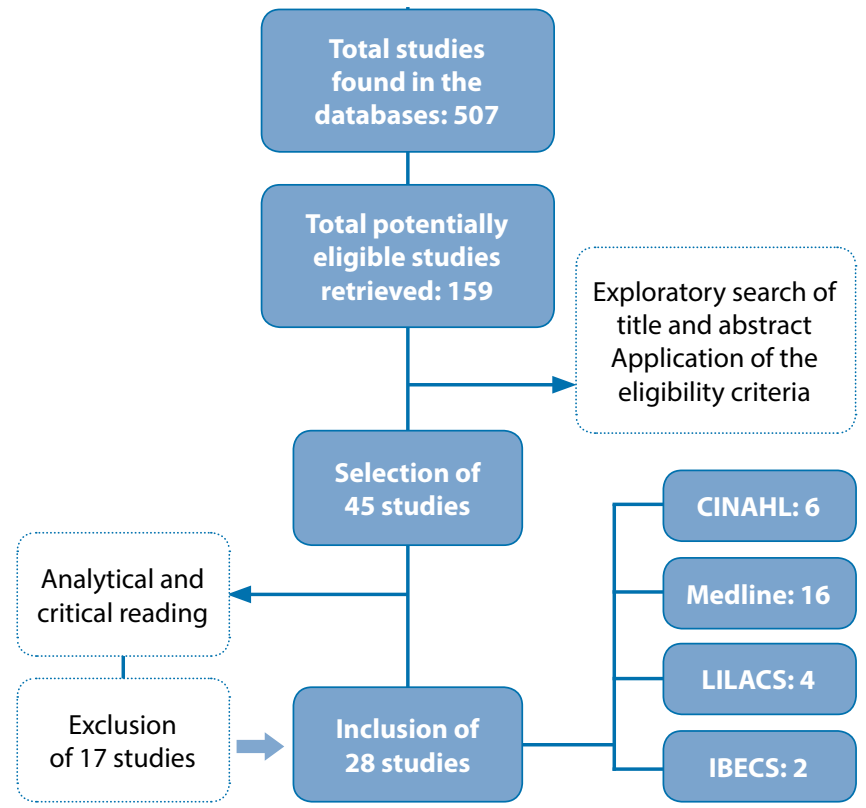

Figure 1 - Flowchart of studies selection $-\mathrm{n}=28$, Belo Horizonte, Minas Gerais, Brazil, 2020
The articles were analyzed according to the etiology of the lesion, the bacteriological profile, and the culture method used to identify the microorganism. The data extracted from the studies were analyzed using descriptive statistics.

\section{RESULTS}

The search in the databases resulted in 507 studies; and, after sorting by title, abstract, and application of the inclusion and exclusion criteria, 43 articles were selected. Then, all of them were submitted to full and critical reading, culminating in the selection of 28 studies of which 16 (57.1\%) were found in the Medline database ${ }^{(9-2)} ; 6$ (21.4\%), in the BVS database ${ }^{(25-30)}$, of which $66.7 \%(\mathrm{n}=4)$ in the LILACS database ${ }^{(26-28,30)}$ and $33.3 \%(\mathrm{n}$ $=2$ ) in the IBECS databases ${ }^{(25,29)}$; and 6 articles (21.4\%) found at CINAHL ${ }^{(31-36)}$.

As for the year of publication, $7.1 \%$ matched $2009^{(9,25)} ; 10.7 \%$, $2010^{(10-11,31)} ; 3.6 \%, 2012^{(26)} ; 3.6 \%, 2013^{(12)} ; 7.1 \%, 2014^{(13,27)} ; 10.7 \%$, $2015^{(14,28-29)} ; 3.6 \%, 2016^{(115)} ; 25 \%, 2017^{(16-20,30,32)} ; 25 \%, 2018^{(21-24,33-35) ;}$ and $3.6 \%, 2019^{(36)}$. Regarding the country of the study, $21.4 \%$ were done in India ${ }^{(12,15,18,22-24)} ; 21.4 \%$, in Brazil ${ }^{(13,20,26-28,30)} ; 10.7 \%$, in China ${ }^{(11,21,32) ;} 7.1 \%$, in Turkey ${ }^{(16,35)} ; 10.7 \%$, in Spain ${ }^{(25,29,36)}$; and $7.1 \%$, in Mexico ${ }^{(14,17)}$. The United Kingdom ${ }^{(9)}$, France ${ }^{(10)}$, Australia ${ }^{(33)}$, Nigeria ${ }^{(31)}$, Indonesia ${ }^{(19)}$, and Saudi Arabia ${ }^{(34)}$ all had the same percentage of identified studies 3.6\% (Chart 1).

Regarding the etiology of ulcers with infection, $78.6 \%$ were due to diabetes ${ }^{(10-12,14-19,21-25,28,30-36)} ; 21.4 \%$, venous $s^{(9,13,20,26-27,29)}$; and $3.6 \%$, arterial ${ }^{(29)}$. Regarding the location of the studies, $35.7 \%$ were outpatient $(13,16,20,23,26-27,29,31,33,36)$, and $64.2 \%$ occurred in hospital un its $^{(9-12,14-15,17-19,21-22,24-25,28,30,32,34-35)}$.

Chart 1 - Summary of selected articles $-\mathrm{n}=28$, Belo Horizonte, Minas Gerais, Brazil, 2020

\begin{tabular}{|c|c|c|c|c|}
\hline Reference & $\begin{array}{l}\text { Year/ } \\
\text { Country }\end{array}$ & $\begin{array}{l}\text { Study } \\
\text { design/ } \\
\text { Sample }\end{array}$ & Interventions & Outcome \\
\hline $\begin{array}{l}\text { Cooper RA, Ameen H, Price P, McCulloch DA, } \\
\text { Harding KG. A clinical investigation into the } \\
\text { microbiological status of 'locally infected' leg } \\
\text { ulcers }^{(9)}\end{array}$ & $\begin{array}{l}2009 \\
\text { United } \\
\text { Kingdom }\end{array}$ & $\begin{array}{l}\text { Descriptive } \\
n=20\end{array}$ & $\begin{array}{l}\text { Qualitative and quantitative } \\
\text { assessment of the } \\
\text { microbiological status of } \\
\text { venous leg ulcers. }\end{array}$ & $\begin{array}{l}\text { Detection of } 5.8 \text { microorganisms per } \\
\text { ulcers. }\end{array}$ \\
\hline $\begin{array}{l}\text { Sotto A, Richard JL, Combescure C, Jourdan N, } \\
\text { Shuldiner S, Bouziges N. et al. Beneficial effects } \\
\text { of implementing guidelines on microbiology } \\
\text { and costs of infected diabetic foot ulcers }\end{array}$ & $\begin{array}{l}2010 \\
\text { France }\end{array}$ & $\begin{array}{l}\text { Cross- } \\
\text { sectional } \\
\mathrm{n}=405\end{array}$ & $\begin{array}{l}\text { Implementation of } \\
\text { guidelines on microbiology } \\
\text { and the costs of infected } \\
\text { diabetic ulcers. Comparison } \\
\text { of bacteriological data and } \\
\text { costs related to the use of } \\
\text { antimicrobials. }\end{array}$ & $\begin{array}{l}\text { Prevalence of MRSA and savings in } \\
\text { costs and workload. }\end{array}$ \\
\hline $\begin{array}{l}\text { Wang SH, Sun ZL, Guo YJ, Yang BQ, Yuan Y, Wei } \\
\text { Q. et al. Meticillin-resistant Staphylococcus } \\
\text { aureus isolated from foot ulcers in diabetic } \\
\text { patients in a Chinese care hospital: risk factors } \\
\text { for infection and prevalence }{ }^{(11)}\end{array}$ & $\begin{array}{l}2010 \\
\text { China }\end{array}$ & $\begin{array}{l}\text { Case-control } \\
\mathrm{n}=118\end{array}$ & Culture and antibiogram & $\begin{array}{l}\text { Staphylococcus aureus was the most } \\
\text { frequent microorganism. MRSA } \\
\text { identification. }\end{array}$ \\
\hline $\begin{array}{l}\text { Shanmugam P, Jeya M, Linda Susan S. The } \\
\text { Bacteriology of Diabetic Foot Ulcers, with } \\
\text { a Special Reference to Multidrug Resistant } \\
\text { Strains }{ }^{(12)}\end{array}$ & $\begin{array}{l}2013 \\
\text { India }\end{array}$ & $\begin{array}{l}\text { Descriptive } \\
\mathrm{n}=50\end{array}$ & $\begin{array}{l}\text { Evaluation of the } \\
\text { microbiological profile of } \\
\text { diabetic ulcers - collection of } \\
\text { samples for microbial culture. }\end{array}$ & $\begin{array}{l}\text { Gram-negatives were more prevalent. } \\
\text { Presence of multidrug resistance } \\
\text { microorganisms }\end{array}$ \\
\hline $\begin{array}{l}\text { Souza JM, Vieira EC, Cortez TM, Mondelli } \\
\text { LA, Miot HA, Abbade LPF. Clinical and } \\
\text { Microbiologic Evaluation of Chronic Leg Ulcers: } \\
\text { A Crosssectional Study }{ }^{(13)}\end{array}$ & $\begin{array}{l}2014 \\
\text { Brazil }\end{array}$ & $\begin{array}{l}\text { Cross- } \\
\text { sectional } \\
\mathrm{n}=77\end{array}$ & $\begin{array}{l}\text { Microbial culture to assess } \\
\text { the bacteriological profile } \\
\text { of leg ulcers. }\end{array}$ & $\begin{array}{l}\text { Gram-negatives were more frequent, } \\
\text { and infected ulcers had a higher } \\
\text { microbial load. }\end{array}$ \\
\hline
\end{tabular}




\begin{tabular}{|c|c|c|c|c|}
\hline Reference & $\begin{array}{l}\text { Year/ } \\
\text { Country }\end{array}$ & $\begin{array}{l}\text { Study } \\
\text { design/ } \\
\text { Sample }\end{array}$ & Interventions & Outcome \\
\hline $\begin{array}{l}\text { Garcia EC, González RG, Albor AR, Salazar- } \\
\text { Schettino. Infections of Diabetic Foot Ulcers } \\
\text { With Methicillin-Resistant Staphylococcus } \\
\text { aureus }^{(14)}\end{array}$ & $\begin{array}{l}2015 \\
\text { Mexico }\end{array}$ & $\begin{array}{l}\text { Descriptive } \\
n=100\end{array}$ & $\begin{array}{l}\text { Microbial culture to assess } \\
\text { the bacteriological profile of } \\
\text { diabetic foot ulcers. }\end{array}$ & $\begin{array}{l}\text { Prevalence of Staphylococcus aureus, } \\
\text { Escherichia coli, and MRSA. }\end{array}$ \\
\hline $\begin{array}{l}\text { Shettigar K, Jain S, Bhat DV, Achrya R, } \\
\text { Ramachandra L, Satyamoorthy K et al. Virulence } \\
\text { determinants in clinical Staphylococcus } \\
\text { aureus from monomicrobial and polymicrobial } \\
\text { infections of diabetic foot ulcers }^{(15)}\end{array}$ & $\begin{array}{l}2016 \\
\text { India }\end{array}$ & $\begin{array}{l}\text { Prospective } \\
\text { cohort } \\
n=200\end{array}$ & $\begin{array}{l}\text { Microbial culture and } \\
\text { chromosomal typing of } \\
\text { genes that encode biofilm } \\
\text { production. }\end{array}$ & $\begin{array}{l}\text { Monomicrobial and polymicrobial } \\
\text { infections; predominance of } \\
\text { Staphylococcus aureus and presence } \\
\text { of biofilm. }\end{array}$ \\
\hline $\begin{array}{l}\text { Ertugrul BM, Lipsky BA, Ture M, Sakarya S. } \\
\text { Risk Factors for Infection with Pseudomonas } \\
\text { aeruginosa in Diabetic Foot Infections }{ }^{(16)}\end{array}$ & $\begin{array}{l}2017 \\
\text { Turkey }\end{array}$ & $\begin{array}{l}\text { Descriptive } \\
\mathrm{n}=174\end{array}$ & Microbiological analysis & $\begin{array}{l}\text { Prevalence of Pseudomonas } \\
\text { aeruginosa and } \\
\text { Staphylococcus aureus. }\end{array}$ \\
\hline $\begin{array}{l}\text { Sánchez-Sanchez M, Cruz-Pulido WL, } \\
\text { Bladinieres-Cámara E, Alcalá-Durán R, Rivera- } \\
\text { Sánchez G, Bocanegra-Garcia V. Bacterial } \\
\text { Prevalence and Antibiotic Resistance in Clinical } \\
\text { Isolates of Diabetic Foot Ulcers in the Northeast } \\
\text { of Tamaulipas, Mexico }{ }^{(17)}\end{array}$ & $\begin{array}{c}2017 \\
\text { Mexico }\end{array}$ & $\begin{array}{l}\text { Observational } \\
\qquad \mathrm{n}=215\end{array}$ & Culture and antibiogram & $\begin{array}{l}\text { Staphylococcus aureus and } \\
\text { Enterobacter sp. were more common, } \\
\text { and penicillin and dicloxacillin were } \\
\text { more effective against Gram-positive } \\
\text { bacteria. }\end{array}$ \\
\hline $\begin{array}{l}\text { Noor S, Borse AG, Ozair M, Raghav A, Parwez I, } \\
\text { Ahmad J. Inflammatory Markers as Risk Factors } \\
\text { for Infection with multidrug - resistance } \\
\text { microbes in diabetic foot subjects }{ }^{(18)}\end{array}$ & $\begin{array}{l}2017 \\
\text { India }\end{array}$ & $\begin{array}{l}\text { Descriptive } \\
n=65\end{array}$ & $\begin{array}{l}\text { Culture of wound aspirates } \\
\text { and soft tissue biopsy for } \\
\text { microbiological evaluation }\end{array}$ & $\begin{array}{l}\text { Gram-negatives were more frequent } \\
\text { than Gram-positives, and } 57 \% \text { of } \\
\text { patients had a positive culture for } \\
\text { multidrug resistance microorganisms. }\end{array}$ \\
\hline $\begin{array}{l}\text { Pemayun TGD, Naibaho RM. Clinical profile and } \\
\text { outcome of diabetic foot ulcer, a view from } \\
\text { tertiary care hospital in Semarang }^{(19)}\end{array}$ & $\begin{array}{c}2017 \\
\text { Indonesia }\end{array}$ & $\begin{array}{l}\text { Descriptive } \\
n=189\end{array}$ & Analysis of medical records & $\begin{array}{l}\text { Gram-negatives were more common; } \\
\text { in } 36.3 \% \text {, lower limb amputations } \\
\text { and multiple amputations occurred } \\
\text { in seven patients. The mortality rate } \\
\text { reached } 10.7 \% \text {. }\end{array}$ \\
\hline $\begin{array}{l}\text { Santos SLV, Martins MA, Prado MA, Soriano } \\
\text { JV, Bachion MM. Are there clinical signs and } \\
\text { symptoms of infection to indicate the presence } \\
\text { of multidrug-resistant bacteria in venous } \\
\text { ulcers? }{ }^{(20)}\end{array}$ & $\begin{array}{l}2017 \\
\text { Brazil }\end{array}$ & $\begin{array}{l}\text { Cross- } \\
\text { sectional } \\
n=69\end{array}$ & $\begin{array}{l}\text { Clinical observation and } \\
\text { microbiological culture of } \\
\text { the lesions. }\end{array}$ & $\begin{array}{l}\text { Two indicators of infection were } \\
\text { predominant: discoloration of the } \\
\text { opaque and/or dark red type and } \\
\text { increase in the volume of exudate; } \\
\text { and positive culture for Staphylococcus } \\
\text { aureus and Pseudomonas spp. It } \\
\text { occurred in } 31.6 \% \text { of the samples. }\end{array}$ \\
\hline $\begin{array}{l}\text { Wu M, Pan H, Leng W, Lei X, Chen Liu, Liang } \\
\text { Z. et al. Distribution of Microbes and Drug } \\
\text { Susceptibility in Patients with Diabetic Foot } \\
\text { Infections in Southwest China }{ }^{(21)}\end{array}$ & $\begin{array}{l}2018 \\
\text { China }\end{array}$ & $\begin{array}{l}\text { Cross- } \\
\text { sectional } \\
\mathrm{n}=428\end{array}$ & $\begin{array}{l}\text { Culture and antibiogram of } \\
\text { deep ulcer secretion. }\end{array}$ & $\begin{array}{l}\text { Multiple pathogen infections; } 36.9 \% \text {, } \\
\text { gram-positive strains; } 51 \% \text {, Gram- } \\
\text { negative bacilli; and 12.1\%, fungi } \\
\text { strains. }\end{array}$ \\
\hline $\begin{array}{l}\text { Noor S, Raghav A, Parwez I, Ozair M, Ahmad } \\
\text { J. Molecular and culture based assessment of } \\
\text { bacterial pathogens in subjects with diabetic } \\
\text { foot ulcer }{ }^{(22)}\end{array}$ & $\begin{array}{l}2018 \\
\text { India }\end{array}$ & $\begin{array}{l}\text { Prospective } \\
\text { cohort } \\
n=50\end{array}$ & $\begin{array}{l}\text { Conventional biochemical } \\
\text { and genomic assays, } \\
\text { polymerase chain reaction. }\end{array}$ & $\begin{array}{l}\text { Most prevalent pathogens: Klebsiella } \\
\text { pneumoniae, Staphylococcus aureus, } \\
\text { Pseudomonas aeruginosa and } \\
\text { Escherichia coli. }\end{array}$ \\
\hline $\begin{array}{l}\text { Pugazhendhi S, Dorairaj AP. Appraisal of } \\
\text { Biofilm Formation in Diabetic Foot Infections } \\
\text { by Comparing Phenotypic Methods With the } \\
\text { Ultrastructural Analysis }{ }^{(23)}\end{array}$ & $\begin{array}{l}2018 \\
\text { India }\end{array}$ & $\begin{array}{l}\text { Descriptive } \\
n=160\end{array}$ & Culture and antibiogram & $\begin{array}{l}\text { Microbial resistance was identified in } \\
\text { biofilm-producing microorganisms. } \\
\text { Most frequent microorganisms } \\
\text { were Staphylococcus aureus and } \\
\text { Pseudomonas aeruginosa. } \\
\end{array}$ \\
\hline $\begin{array}{l}\text { Sonal SM, Rodrigues GS, Vyasc N, } \\
\text { Mukhopadhyay C. Antimicrobial susceptibility } \\
\text { pattern of aerobes in diabetic foot ulcers in a } \\
\text { South-Indian tertiary care hospital }\end{array}$ & $\begin{array}{l}2018 \\
\text { India }\end{array}$ & $\begin{array}{l}\text { Cross- } \\
\text { sectional } \\
n=260\end{array}$ & Culture and antibiogram & $\begin{array}{l}\text { Monomicrobial infections were } \\
\text { less common than polymicrobial. } \\
\text { Gram-negative bacteria were } \\
\text { the most common among the } \\
\text { isolates. Staphylococcus aureus and } \\
\text { Pseudomonas } \\
\text { aeruginosa were the most frequent. }\end{array}$ \\
\hline $\begin{array}{l}\text { Martínez-Gomes DA, Ramírez-Almagro C, } \\
\text { Campillo-Soto A, Morales-Cuenca G, Pagán- } \\
\text { Ortiz J, Aguayo-Albasini JL. Infecciones del } \\
\text { pie diabético: prevalencia de los distintos } \\
\text { microorganismos y sensibilidad a los } \\
\text { antimicrobianos }^{(25)}\end{array}$ & $\begin{array}{l}2009 \\
\text { Spain }\end{array}$ & $\begin{array}{l}\text { Prospective } \\
\text { cohort } \\
n=62\end{array}$ & Culture and antibiogram & $\begin{array}{l}\text { Predominance of Gram-positive } \\
\text { microorganisms; } \\
\text { Staphylococcus aureus was the most } \\
\text { common. }\end{array}$ \\
\hline
\end{tabular}




\begin{tabular}{|c|c|c|c|c|}
\hline Reference & $\begin{array}{l}\text { Year/ } \\
\text { Country }\end{array}$ & $\begin{array}{l}\text { Study } \\
\text { design/ } \\
\text { Sample }\end{array}$ & Interventions & Outcome \\
\hline $\begin{array}{l}\text { Martins MA, Santos SLV, Leão LSNO, Araujo } \\
\text { NP, Bachion MM. Prevalence of resistance } \\
\text { phenotypes in Staphylococcus aureus and } \\
\text { coagulase-negative isolates of venous ulcers of } \\
\text { primary healthcare patients }\end{array}$ & $\begin{array}{l}2012 \\
\text { Brazil }\end{array}$ & $\begin{array}{l}\text { Cross- } \\
\text { sectional } \\
n=69\end{array}$ & & $\begin{array}{l}\text { The prevalence of Staphylococcus } \\
\text { aureus was } 83 \% \text { and } 15 \% \text { of } \\
\text { coagulase-negative Staphylococcus, } \\
\text { in addition to methicillin-resistant } \\
\text { Staphylococcus aureus (MRSA) } \\
\text { and } 47 \% \text { of coagulase-resistant } \\
\text { Staphylococcus-negative. }\end{array}$ \\
\hline $\begin{array}{l}\text { Santos SLV, Martins MA, Vasconcelos LSNOL, } \\
\text { Lima ABM, Malaquias SG, Bachion MM. Gram- } \\
\text { negative rods in venous ulcers and implications } \\
\text { for nursing care in Primary Care }{ }^{(27)}\end{array}$ & $\begin{array}{l}2014 \\
\text { Brazil }\end{array}$ & $\begin{array}{l}\text { Cross- } \\
\text { sectional } \\
n=64\end{array}$ & $\begin{array}{l}\text { Interview, clinical } \\
\text { examination, photographic } \\
\text { record, and swabbing of the } \\
\text { lesions. }\end{array}$ & $\begin{array}{l}\text { Pseudomonas aeruginosa and } \\
\text { Escherichia coli prevailed. }\end{array}$ \\
\hline $\begin{array}{l}\text { Perim MC, Borges JC, Celeste SRC, Orsolin EF, } \\
\text { Mendes RR, Mendes GO, et al. Aerobic bacterial } \\
\text { profile and antibiotic resistance in patients with } \\
\text { diabetic foot infections }\end{array}$ & $\begin{array}{l}2015 \\
\text { Brazil }\end{array}$ & $\begin{array}{l}\text { Prospective } \\
\text { cohort } \\
n=41\end{array}$ & Culture and antibiogram & $\begin{array}{l}\text { The infections were predominantly } \\
\text { polymicrobial. The most common } \\
\text { Gram-positive bacteria were } \\
\text { Staphylococcus Aureus; and Gram- } \\
\text { negative, Proteus spp. }\end{array}$ \\
\hline $\begin{array}{l}\text { Balbuena JO, Madero RG, Gómez TS, Caballero } \\
\text { MC, Romero IS, Martínez AR. Microbiología de } \\
\text { las infecciones de úlceras por presión y de origen } \\
\text { vascular (29) }\end{array}$ & $\begin{array}{l}2015 \\
\text { Spain }\end{array}$ & $\begin{array}{l}\text { Cross- } \\
\text { sectional } \\
\mathrm{n}=159\end{array}$ & Microbiological culture & $\begin{array}{l}\text { Higher number of infections caused } \\
\text { by enterobacteria } \\
\text { and a lower number of S. aureus } \\
\text { infections in patients with pressure } \\
\text { injuries compared to those with } \\
\text { venous ulcers. Of the isolated strains } \\
\text { of } S \text {. aureus, } 41 \% \text { were resistant to } \\
\text { methicillin (MRSA). }\end{array}$ \\
\hline $\begin{array}{l}\text { Cardoso NA, Cisneiros LL, Machado CJ, } \\
\text { Cenedezi JM, Procópio RJ, Navarro TP. Bacterial } \\
\text { genera is a risk factor for major amputation in } \\
\text { patients with diabetic foot }{ }^{(30)}\end{array}$ & $\begin{array}{l}2017 \\
\text { Brazil }\end{array}$ & $\begin{array}{l}\text { Case-control } \\
\mathrm{n}=189\end{array}$ & $\begin{array}{l}\text { Deep tissue culture of } \\
\text { lesions - Biopsy }\end{array}$ & $\begin{array}{l}\text { Cultures were positive in } 86.8 \% \text {, with } \\
\text { monomicrobial in } 72 \% . \text { In patients } \\
\text { with major amputation, the most } \\
\text { frequent bacterial genera were } \\
\text { Acinetobacter spp. }\end{array}$ \\
\hline $\begin{array}{l}\text { Agwu E, Lhongbe J, Inyang N. Prevalence } \\
\text { of Quinolone-susceptible Pseudomonas } \\
\text { aeruginosa and Staphylococcus aureus in } \\
\text { Delayed-healing DFU's in Ekpoma, Nigeria(31) }\end{array}$ & $\begin{array}{c}2010 \\
\text { Nigeria }\end{array}$ & $\begin{array}{l}\text { Descriptive } \\
n=220\end{array}$ & Culture and antibiogram & $\begin{array}{l}\text { Predominance of Pseudomonas } \\
\text { aeruginosa, Staphylococcus aureus, and } \\
\text { co-infection by both microorganisms. }\end{array}$ \\
\hline $\begin{array}{l}\text { Xie X, Bao Y, Ni L, Liu D, NiuS, Lin H et al. } \\
\text { Bacterial Profile and Antibiotic Resistance in } \\
\text { Patients with Diabetic Foot Ulcer in Guangzhou, } \\
\text { Southern China: Focus on the Differences } \\
\text { among Different Wagner's Grades, IDSA/IWGDF } \\
\text { Grades, and Ulcer Types }\end{array}$ & $\begin{array}{l}2017 \\
\text { China }\end{array}$ & $\begin{array}{c}\text { Descriptive } \\
n=117\end{array}$ & Culture and antibiogram & $\begin{array}{l}\text { The proportion of Gram-negative } \\
\text { bacteria was higher than that } \\
\text { of Gram-positive bacteria, with } \\
\text { Enterobacteriaceae and Staphylococcus } \\
\text { standing out. }\end{array}$ \\
\hline $\begin{array}{l}\text { Arjunan SP, Tint AN, Aliahmad B, Kumar DK, } \\
\text { Shukla R, Miller J et al. High-Resolution Spectral } \\
\text { Analysis Accurately Identifies the Bacterial } \\
\text { Signature in Infected Chronic Foot Ulcers in } \\
\text { People With Diabetes. SAGE } \\
\text { (33) }\end{array}$ & $\begin{array}{c}2018 \\
\text { Australia }\end{array}$ & $\begin{array}{l}\text { Descriptive } \\
n=18\end{array}$ & $\begin{array}{l}\text { Swab and high-resolution } \\
\text { spectroscopy of the wound } \\
\text { center and peri-wound area } \\
\text { for multispectral estimation } \\
\text { of bacteria at the base of } \\
\text { diabetic foot ulcers. }\end{array}$ & $\begin{array}{l}\text { Swab: presence of Staphylococcus } \\
\text { aureus and Escherichia coli. The results } \\
\text { of the multispectral analysis showed } \\
100 \% \text { sensitivity, with } 100 \% \text { negative } \\
\text { predictive values for identifying the } \\
\text { presence of the bacteria, which was } \\
\text { the cause of the wound infection. }\end{array}$ \\
\hline $\begin{array}{l}\text { Ayed MYA, Ababneh M, Robert AA, Alzaid A, } \\
\text { Ahmed RA, Salman A, et al. Common Pathogens } \\
\text { and Antibiotic Sensitivity Profiles of Infected } \\
\text { Diabetic Foot Ulcers in Saudi Arabia } \\
\end{array}$ & $\begin{array}{l}2018 \\
\text { Saudi } \\
\text { Arabia }\end{array}$ & $\begin{array}{l}\text { Descriptive } \\
n=126\end{array}$ & Culture and antibiogram & $\begin{array}{l}\text { Pseudomonas aeruginosa and } \\
\text { Staphylococcus aureus were the most } \\
\text { frequent microorganisms. }\end{array}$ \\
\hline $\begin{array}{l}\text { Yildiz PA, Özdil T, Dizbay M, Tunçcan OG, Hizel K. } \\
\text { Peripheral arterial disease increases the risk of } \\
\text { multidrug-resistant bacteria and amputation in } \\
\text { diabetic foot infections }^{(35)}\end{array}$ & $\begin{array}{l}2018 \\
\text { Turkey }\end{array}$ & $\begin{array}{c}\text { Descriptive } \\
\mathrm{n}=112\end{array}$ & Analysis of medical records & $\begin{array}{l}\text { Predominance of Gram-positive } \\
\text { bacteria. Staphylococcus aureus and } \\
\text { Streptococcus spp. were more frequent. } \\
\text { Multidrug-resistant microorganisms } \\
\text { were common in patients with } \\
\text { peripheral arterial disease. }\end{array}$ \\
\hline $\begin{array}{l}\text { Lázaro-Martínez JL, Álvaro-Afonso FJ, Sevillano- } \\
\text { Fernández D, Molines-Barroso RJ, García-Álvarez } \\
\text { Y, García-Morales E. Clinical and Antimicrobial } \\
\text { Efficacy of a Silver Foam Dressing With Silicone } \\
\text { Adhesive in Diabetic Foot Ulcers With Mild } \\
\text { Infection }^{(36)}\end{array}$ & $\begin{array}{l}2019 \\
\text { Spain }\end{array}$ & $\begin{array}{l}\text { Prospective, } \\
\text { open, non- } \\
\text { controled } \\
\mathrm{n}=21\end{array}$ & Culture and antibiogram & $\begin{array}{l}\text { Treatment with a silver dressing } \\
\text { significantly reduced the biological } \\
\text { load of pathogenic foot ulcer } \\
\text { organisms, such as Staphylococcus } \\
\text { aureus, including MRSA, } \\
\text { Enterobacteriaceae, Pseudomonas } \\
\text { aeruginosa, and other non-fermenting } \\
\text { Gram-negative bacilli. }\end{array}$ \\
\hline
\end{tabular}




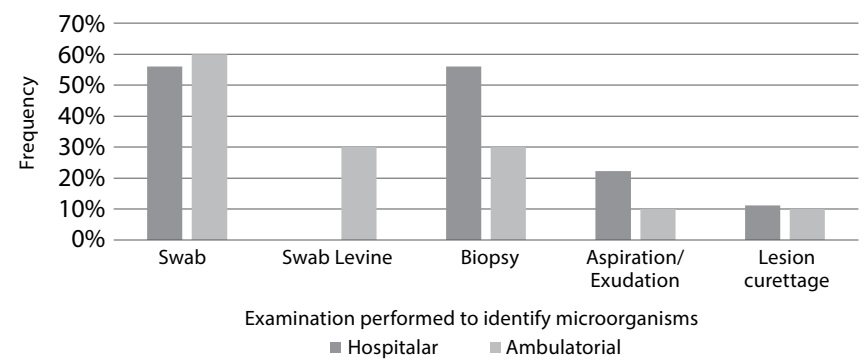

Figure 2 - Type of examination performed to identify microorganisms according to the scenario of care of the individuals in the studies $-n=28$, Belo Horizonte, Minas Gerais, Brazil, 2020

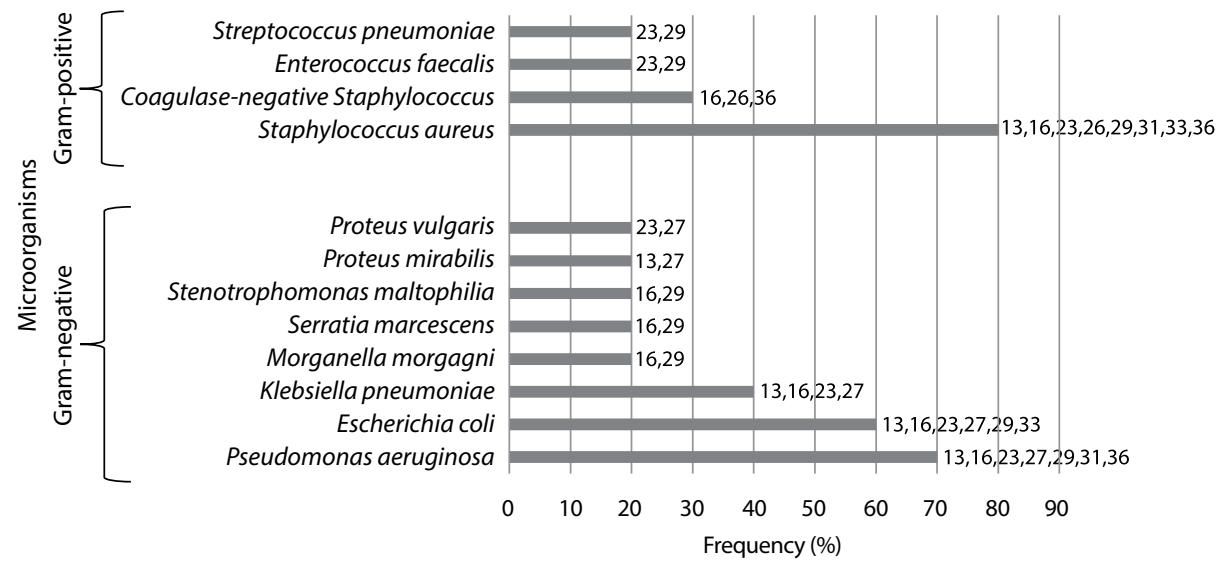

Figure 3 - Profile of isolated microorganisms in outpatient care - n=10, Belo Horizonte, Minas Gerais, Brazil, 2020

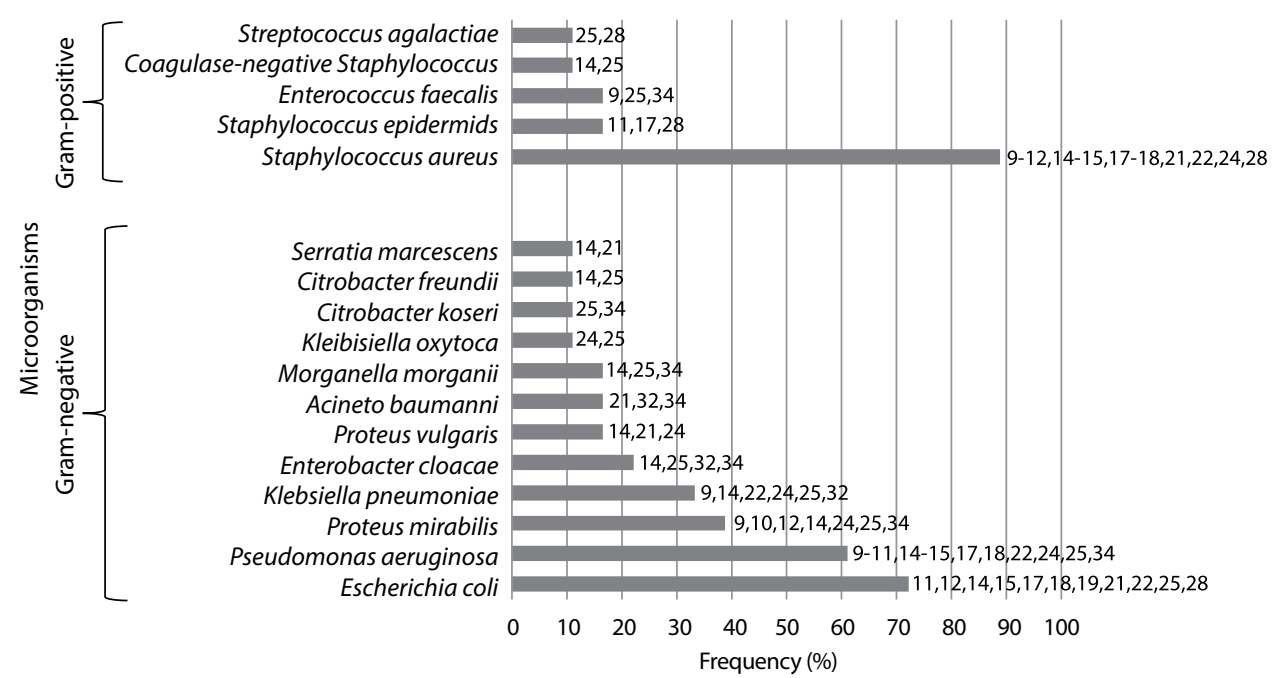

Figure 4 - Profile of isolated microorganisms in hospital care - n=18, Belo Horizonte, Minas Gerais, Brazil, 2020.
Regarding the microbiological profile (Figure 3), a higher proportion of Gram-negative microorganisms was identified in patients seen at an outpatient clinic, with Escherichia coli species being more common in $60 \%$ of the studies ${ }^{(13,16,23,27,29,33)}$ and Pseudomonas aeruginosa in $70 \%(13,16,23,27,29,31,36)$. As for Gram-positive microorganisms, Staphylococcus aureus was predominant in $80 \%$ of the studies ${ }^{(13,16,23,26,29,31,33,36)}$.

Other Gram-negatives were isolated with a lower frequency, such as Citrobacter freundii, Enterobacter gergovia, Klebsiella oxytoca, Morganela morganii, Pantoea aglomerans, Providencia rettgeri, Enterobacter aerogenes ${ }^{(27)}$, Salmonella paratyphi, Vibrio parahaemolyticus, Shigella sonnei, Pleisomonas shigelloides ${ }^{(23)}$, Acitetobacterbaumanii, Providencia stuartii(29), and Proteus penneri ${ }^{(13)}$, Enterobacteriaceae, Streptococcus sp. and non-fermenting Gramnegative bacilli( ${ }^{(36)}$. Among the Gram-positive species, they were: Staphylococcus saprophyticus and epidermidis, Micrococcus/uteus ${ }^{(23)}$, Staphylococcus lugdunensis and Streptococcus pyogenes ${ }^{(29)}$. Some genera of isolated microorganisms were not specified, such as, Enterococcus spp. ${ }^{(16)}$, Corynebacterium sp. ${ }^{(36)}$, and Citrobacter spp. . $^{(27)}$.

Regarding hospital care (Figure 4), Gram-negative species predominated, the most common being Escherichia coli, present in $72.2 \%$ of the studies $^{(11-12,14-15,17-19,21-22,25,28,32,34)}$; and Pseudomonas aeruginosa, in $61.1 \%{ }^{(9-11,14-15,17-18,22,24-25,34)}$. Grampositive results were Staphylococcus aureus, in $88.8 \% \%^{(9-12,14-15,17-}$ 18,21-22,24-25,28,32,34-35). Gram-negatives were identified in the frequency of $5.5 \%$ of the studies, with emphasis on Enterobacter hafnie, Enterobacter agglomerans, Enterobacter aerogenes ${ }^{(14)}$, Citrobacter amalonaticus ${ }^{(21)}$, Citrobacter diversus ${ }^{(17)}$, and Xanthomonas maltophilia ${ }^{(25)}$; and the positive ones were Staphylococcus saprophyticus, Streptococcus pneumoni$a e^{(28)}$, Streptococcus viridans ${ }^{(25)}$, Staphylococcus haemolyticus ${ }^{(11)}$, Corynebacterium striatum ${ }^{(9)}$, and Streptococcus pyogenes ${ }^{(12)}$.

Isolated genera without species identification were Stenotrophomonas spp. ${ }^{(30)}$, Serratia spp..$^{(14,17,21,30)}$, Clostridium spp., Prevotella spp. ${ }^{(25)}$, and Peptostreptococcus spp. ${ }^{(19,25)}$.

Regarding the microorganism's resistance profile, $75 \%$ of the studies identified multidrug-resistant, Gram-positive and Gram-negative bacteria; 7 of them were performed on an outpatient basis, and 14, in hospital units. Among the patients treated in outpatient clinics, Gram-positive, resistant to methicillin, were isolated, being $71.4 \%$ technique with greater quantitative recovery of microorganisms). 
Staphylococcus aureus ${ }^{(16,20,23,26,36)}, 28.5 \%$ coagulase-negative Staphylococcus ${ }^{(16,26)}$, and $16.7 \%$ Staphylococcus epidermidis ${ }^{(23)}$, while in the Gram-negative group, pseudomonas aeruginosa resistant to cefoxitin and trimethoprim-sulfamethoxazole ${ }^{(27)}$ stood out. Microorganisms isolated from ulcers in hospitalized patients are described in Table 1.

Table 1 - Main microorganisms resistant to the most frequent antibiotics of leg ulcers in hospitalized patients $-n=14$, Belo Horizonte, Minas Gerais, Brazil, 2020

\begin{tabular}{|c|c|c|}
\hline $\begin{array}{l}\text { Resistant } \\
\text { Microorganisms }\end{array}$ & Antibiotic(s) & n (\%) \\
\hline \multicolumn{3}{|l|}{ Gram-positives } \\
\hline $\begin{array}{l}\text { Staphylococcus } \\
\text { aureus }\end{array}$ & $\begin{array}{l}\text { Methicillin } \\
\text { Penicillin } \\
\text { Tetracycline } \\
\text { Ciprofloxacino } \\
\text { Gentamycin } \\
\text { Erythromycin } \\
\text { Amoxicillin + clavulanic acid } \\
\text { Cefoxitin } \\
\text { Cephalothin } \\
\text { Sulfamethoxazole + trimetho } \\
\text { Vancomycin } \\
\text { Oxacillin } \\
\text { Ampicillin }\end{array}$ & $\begin{array}{l}8(57.1)^{(10-11,14,21,24,32,34-35)} \\
5(35.7)^{(12,17,25,28,32)} \\
2(14.3)^{(12,17)} \\
3(21.4)^{(12,15,25)} \\
4(28.6)^{(12,15,17,25)} \\
5(35.7)^{(12,15,17,25,28)} \\
3(21.4)^{(15,25,28)} \\
3(21.4)^{(14-15,28)} \\
2(14.3)^{(17,28)} \\
2(14.3)^{(17,28)} \\
3(21.4)^{(17,25,28)} \\
3(21.4)^{(14,25,28)} \\
2(14.3)^{(15,17)}\end{array}$ \\
\hline $\begin{array}{l}\text { Staphylococcus } \\
\text { epidermidis }\end{array}$ & $\begin{array}{l}\text { Cephalothin } \\
\text { Erythromycin } \\
\text { Penicillin } \\
\text { Sulfamethoxazole + trimetho } \\
\text { Vancomycin }\end{array}$ & $\begin{array}{l}2(14.3)^{(17,28)} \\
2(14.3)^{(17,28)} \\
2(14.3)^{(17,28)} \\
2(14.3)^{(17,28)} \\
2(14.3)^{(17,21)}\end{array}$ \\
\hline \multicolumn{3}{|l|}{ Gram-negatives } \\
\hline Escherichia coli & $\begin{array}{l}\text { Amikacin } \\
\text { Ampicillin } \\
\text { Aztreonam } \\
\text { Cefotaxime } \\
\text { Cefepime } \\
\text { Cefoperazone } \\
\text { Ciprofloxacin } \\
\text { Gentamycin } \\
\text { Tobramycin } \\
\text { Ceftriaxone } \\
\text { Sulbactam } \\
\text { Amoxicillin + clavulanic acid }\end{array}$ & $\begin{array}{l}3(21.4)^{(12,17-18)} \\
4(28.6)^{(12,17,25,28)} \\
2(14.3)^{(12,28)} \\
3(21.4)^{(12,17,28)} \\
3(21.4)^{(12,17-18)} \\
2(14.3)^{(12,18)} \\
2(14.3)^{(12,25)} \\
4(28.6)^{(12,17-18,28)} \\
2(14.3)^{(12,18)} \\
2(14.3)^{(17-18)} \\
2(14.3)^{(12,18)} \\
2(14.3)^{(25,28)}\end{array}$ \\
\hline $\begin{array}{l}\text { Pseudomonas } \\
\text { aeruginosa }\end{array}$ & $\begin{array}{l}\text { Amikacin } \\
\text { Levofloxacin } \\
\text { Cefepime }\end{array}$ & $\begin{array}{l}2(14.3)^{(17-18)} \\
2(14.3)^{(17-18)} \\
2(14.3)^{(17-18)}\end{array}$ \\
\hline
\end{tabular}

\section{DISCUSSION}

The infection of leg ulcers significantly impacts the patient and health services; thus, its occurrence must be identified early. Infections can have a monomicrobial or polymicrobial etiology and still have microorganisms resistant to one or more antibiotics. The predominance of Gram-negative bacteria was similar in outpatient and hospital care, a common finding in studies evaluating the microbiological profile of ulcers ${ }^{(5,30,37)}$. The most common Gram-negative microorganisms in leg ulcer infections were the specimens Pseudomonas aeruginosa and Escherichia coli, while among the positive ones, Staphylococcus aureus predominated, findings that corroborate other studies ${ }^{(5,38)}$.

These species also presented microbiological selection to one or more antibiotics. Studies that evaluated the resistance profile of microorganisms isolated from infected ulcers also identified the presence of methicillin-resistant Staphylococcus aureus ${ }^{(14,39)}$;
Pseudomonas aeruginosa resistant to classes of cephalosporins, monobactamics, carbapenems, aminoglycosides, chlorophenicol, chylones and fluoroquilones, and $\beta$-lactam inhibitors ${ }^{(40)}$; Antibioticresistant Escherichia coli such as amikacin, imipinem, tazobactam, cefepime, ceftazidime, levofloxacin, ciprofloxaxine, tobramycin, aztreonam, gentamicin, ampicillin, sulbactam, cefazolin, ceftriaxone, ceftriaxine, cefotethane, furantoin, and sulfamethoxazole ${ }^{(41)}$.

The epidemiological importance of infections caused by multidrug-resistant bacteria is emphasized, because when they occur, they can cause serious complications and consequences for affected patients, as well as financially impact health institutions, in addition to increasing the risk of patients' morbidity and mortality ${ }^{(3,42)}$. These infections threaten the protection of patients since they minimize the possibilities of therapeutic options against certain species, which lessen the alternatives for the treatment of bacterial infections ${ }^{(42)}$, prolong the stay in hospitals, treatment, diagnostic procedures and, consequently, increase treatment costs.

The identification of critical colonization as well as the initial signs of infection are essential and must consider the thorough evaluation and the reduction of the bacterial load in the wound bed, involving the techniques for collection of cultures and diagnostic criteria of the infection. Regarding the reduction of bacterial load, in order to minimize critical colonization and possible infection, the importance of a careful cleaning of the wound is highlighted. It can be done using physiological solutions or composed of antimicrobials such as polyhexamethylene biguanide (PHMB); and, when available under pressure, in the form of a jet ${ }^{(43)}$, it helps to minimize the risk of infection.

In the event of an infection, some signs and symptoms should be carefully evaluated, such as edema of the limb or the edges of the lesion ${ }^{(44)}$, hardening, erythema, flushing, pain, and local sensitivity, granulation tissue with a friable characteristic, occurrence of fever, chills, odor, high white blood cell count, delayed healing after two weeks, even under adequate topical therapy, and increased volume and changes in exudate characteristics ${ }^{(45)}$.

In order to facilitate the distinction between clinical signs of infection in the superficial and deep compartments, the bicompartmental model guided by the mnemonics NERDS and STONES was developed in 2007. NERDS was conceived to differentiate "critical colonization" from "infection", being its description: $(\mathrm{N})$ Nonhealing - No wound healing; (E) Exudative - presence of inflammatory exudate; (R) Red and bleeding wound surface granulation tissue - Red and friable granulation tissue; (D) Debris - Debris from tissue; and (S) Smell. STONES reflects the progression from colonization to infection: (S) Size - Increase in the size of the wound; (T) Temperature is increased - Increase in local wound temperature, $(\mathrm{O})$ Os probe to or exposed bone - extent of wound to bone; (N) New or satellite areas of breakdown - Deterioration or new wounds; (E) Exudate, erythema, edema; (S) Smel/(46-47).

The systematic use of these mnemonics, however, is not common in clinical practice, and the guidelines for such care can be inconsistent and incipient. This fact may favor assistance supported by common sense. Therefore, the involvement of stomatherapist nurses is of fundamental importance, considering their expertise in the assessment and treatment of wounds, as well as Infection Control teams in the hospital environment or Primary Care, aiming 
at the best therapeutic conduct or its adequacy and monitoring of microbiological profile of the institution.

Regarding the culture method for the identification of microbial isolates, it is worth mentioning that the quantification of the microbial load is the best indicator of the infectious process ${ }^{(48)}$. The existence of three commonly used techniques is highlighted: biopsy, needle aspiration, and swab. Biopsy is considered the gold standard and consists of the collection of tissue or deep fragments of the wound. However, in some situations, it is not feasible, and swab collection is an acceptable alternative, as it is practical, economical, non-invasive, and allows the identification of infectious bacteria, allowing to guide antibiotic therapy and subsidize sensitivity tests ${ }^{(49)}$. In this sense, the guidelines of the National Pressure Ulcer Advisory Panel (NPUAP) describe that the determination of the microbial load of pressure injury, by tissue biopsy or swab, is recommended with moderate evidence ${ }^{(48)}$. There were no differences in the use of the swab and biopsy in the hospital setting; however, the use of the swab in the outpatient clinic predominated. Swabbing is a frequently used method and is therefore recommended using the Levine technique, since it allows for more assertive quantitative culture when compared to the $Z$ technique ${ }^{(49)}$.

Its execution consists of carefully cleaning the wound with a saline solution, removing the non-viable tissue, after which it is required to wait between two and five minutes (if the bed becomes dry, you must moisten it after that time). Then, in the area in which the tissue appearance appears to be healthier, a sterile swab with a calcium alginate tip must be applied over an area of $1 \mathrm{~cm}^{2}$, applying pressure for five seconds (the pressure must be sufficient for an expressive capture of the tissue fluid). Then, the tip of the swab must be broken in the collection device designed for quantitative cultures ${ }^{(48)}$.

There was a greater occurrence of ulcers due to diabetes, which commonly have a relevant prevalence in health services. In the context of Primary Care, a Brazilian study identified that, among elderly participants, $11.8 \%$ had some chronic wound, with $5 \%$ being affected by pressure injuries; $3.2 \%$, diabetic ulcers; and $2.9 \%$, due to vasculogenic ${ }^{(50)}$. It is emphasized that, when complications occur in diabetic foot ulcers, they directly impact the total treatment costs.

Although there are national and international programs and guidelines for diagnostic criteria for infection, the rational use of antibiotics and control of microbial selection, these are still incipient in the context of chronic leg ulcers, which present infection. Therefore, the discussion of the theme, especially on the instrumentalization of professional nurses on the aspects related to the rapid and accurate identification of the infection process, of methods of microorganism identification, is necessary in order to improve the evidence for care at the ambulatory and hospital level, given that these competencies and responsibilities are inherent to the first therapeutic approach, which is usually the responsibility of nurses who care for wounds.

\section{Study limitations}

Among the limitations identified for the construction of this review, we highlight the following: even though original articles that evaluated infected ulcers were analyzed, eventually some isolates may correspond to critical colonization, which is not, therefore, clearly described in the studies.

As for the swab collection technique, although Levine's was described, it was not mentioned in all studies, which makes it impossible to identify its use as the first choice at the time of culture collection. Finally, studies that used biopsy and swab to perform culture did not stratify the isolates identified by method, separately, so that this analysis was not possible together.

\section{Contributions to the nursing field}

Although the objective of this review does not include the skills of nurses in the care and treatment of infected leg ulcers, it should be noted that these professionals must have skills in the light of suspected infection, clinical-critical judgment in the detection, referrals, and collection of exams. Therefore, the results of this study allow nurses to reflect on the topic for use in clinical practice, regardless of where the care for patients with leg ulcers occurs, since it demonstrates the microbiological profile of chronic wounds, showing the great possibility of bacterial resistance, which can increase patient treatment time and institutional costs.

\section{CONCLUSIONS}

The bacteriological profile of leg ulcer infections was similar between outpatient and hospital care, with a predominance of Gram-negative species. However, the profile of microbiological selection for antibiotics was more expressive in the hospital environment. It was possible to observe that many microorganisms presented microbiological selection to one or more antibiotics. The culture method was similar in the two levels of assistance, but a higher occurrence of biopsy was identified in the hospital service; and swab in the outpatient.

\section{REFERENCES}

1. Agale SV. Chronic leg ulcers: epidemiology, aetiopathogenesis, and management. Ulcers 2013;2013:1-9. https://doi.org/10.1155/2013/413604

2. Guest JF, Ayoub N, Mcllwraith T, Uchegbu I, Gerrish A, Weidlich D, et al. Health economic burden that wounds impose on the National Health Service in the UK. BMJ Open 2015;5(e009283):1-8. https://doi.org/10.1136/ bmjopen-2015-009283

3. Hicks CW, Canner JK, Karagozlu H, Mathioudakis N, Sherman RL, Black JH, et al. The Society for Vascular Surgery Wound, Ischemia, and foot Infection (WIfl) classification system correlates with cost of care for diabetic foot ulcers treated in a multidisciplinary setting. J Vasc Surg. 2018; 67(5):1455-1462. https://doi.org/10.1016/j.jvs.2017.08.090 
4. Rodriguez SP, Machado AD, Delgado CAG, González YG. Crecimiento bacteriano en la úlcera del pie diabético previo al uso de Heberprot-P. Bacterial growth in diabetic foot ulcer prior to Heberprot-P. Rev Cub Med Mil. 2014;43(2):169-75. Available from: http://scielo.sld.cu/pdf/ $\mathrm{mil} / \mathrm{v} 43 \mathrm{n} 2 / \mathrm{mil} 05214 . \mathrm{pdf}$

5. Gelatti CL, Bonamigo RR, Becker AN, Eidt LM, Ganassini L, Azevedo PA. Phenotypic, molecular and antimicrobial susceptibility assessment in isolates from chronic ulcers of cured leprosy patients: a case study in Southern Brazil. An Bras Dermatol. 2014;89(3):404-8. https://doi. org/10.1590/abd1806-4841.20142688

6. Angel DE, Lloyd P, Carville K, Santamaria N. The clinical efficacy of two semiquantitative wound-swabbing techniques in identifying the causative organism(s) in infected cutaneous wounds. Int Wound J. 2011;8(2):176-85. https://doi.org/10.1111/j.1742-481X.2010.00765.x

7. Hewish J. Guidelines for the effective diagnosis and management of local wound bed infection and bacterial colonisation: Tissue Viability [Internet]. 2014[cited 2019 Dec 2];2. Available from: http://www.tvhkt.org.uk/wp-content/uploads/Guidelines-for-the-effective-diagnosisand-management-of-local-wound-bed-infection.pdf

8. Mendes KDS, Silveira RCCP, Galvão CM. Revisão integrativa: método de pesquisa para incorporação de evidências na saúde e na enfermagem. Texto Contexto Enfermagem. 2008;17(4):758-64. https://doi.org/10.1590/S0104-07072008000400018

9. Cooper RA, Ameen H, Price P, McCulloch DA, Harding KG. A clinical investigation into the microbiological status of 'locally infected' leg ulcers. Int Wound J. 2009;6(6):453-62. https://doi.org/10.1111/j.1742-481X.2009.00640.x

10. Sotto A, Richard JL, Combescure C, Jourdan N, Shuldiner S, Bouziges N, et al. Beneficial effects of implementing guidelines on microbiology and costs of infected diabetic foot ulcers. Diabetol. 2010;53:2249-2255. https://doi.org/10.1007/s00125-010-1828-3

11. Wang SH, Sun ZL, Guo YJ, Yang BQ, Yuan Y, Wei Q, et al. Meticillin-resistant Staphylococcus aureus isolated from foot ulcers in diabetic patients in a Chinese care hospital: risk factors for infection and prevalence. J Med Microbiol. 2010;59:1219-24. https://doi.org/10.1099/jmm.0.020537-0

12. Shanmugam $P$, Jeya $M$, Linda Susan S. The bacteriology of diabetic foot ulcers, with a special reference to multidrug resistant strains. J Clin Diagnost Res. 2013;7(3):441-5. https://doi.org/10.7860/JCDR/2013/5091.2794

13. Souza JM, Vieira EC, Cortez TM, Mondelli LA, Miot HA, Abbade LPF. Clinical and microbiologic evaluation of chronic leg ulcers: a crosssectional study. advances in skin e wound care. 2014;27(5):222-7. https://doi.org/10.1097/01.ASW.0000445952.83084.a0

14. Garcia EC, González RG, Albor AR, Salazar-Schettino. Infections of diabetic foot ulcers with methicillin-resistant staphylococcus aureus. Int J Lower Extremy Wounds. 2015;14(1):44 -9. https://doi.org/10.1177/1534734614564053

15. Shettigar K, Jain S, Bhat DV, Achrya R, Ramachandra L, Satyamoorthy K, et al. Virulence determinants in clinical Staphylococcus aureus from monomicrobial and polymicrobial infections of diabetic foot ulcers. J Med Microbiol. 2016;65:1392-404. https://doi.org/10.1099/jmm.0.000370

16. Ertugrul BM, Lipsky BA, Ture M, Sakarya S. Risk factors for infection with pseudomonas aeruginosa in diabetic foot infections. J Am Podiatric Med Assoc. 2017;107(6):483-9. https://doi.org/10.7547/15-167

17. Sánchez-Sanchez M, Cruz-Pulido WL, Bladinieres-Cámara E, Alcalá-Durán R, Rivera-Sánchez G, Bocanegra-Garcia V. Bacterial prevalence and antibiotic resistance in clinical isolates of diabetic foot ulcers in the Northeast of Tamaulipas, Mexico. Int J Lower Extremy Wounds. 2017;1-6. https://doi.org/10.1177/1534734617705254journals.sagepub.com/home/ijl

18. Noor S, Borse AG, Ozair M, Raghav A, Parwez I, Ahmad J. inflammatory markers as risk factors for infection with multidrug - resistance microbes in diabetic foot subjects. Foot. 2017;1-19. https://doi.org/10.1016/j.foot.2017.05.001

19. Pemayun TGD, Naibaho RM. Clinical profile and outcome of diabetic foot ulcer, a view from tertiary care hospital in Semarang, Diabetic Foot E Ankle. 2017;8(1):1-8. https://doi.org/10.1080/2000625X.2017.1312974

20. Santos SLV, Martins MA, Prado MA, Soriano JV, Bachion MM. Are there clinical signs and symptoms of infection to indicate the presence of multidrug-resistant bacteria in venous ulcers? J Vasc Nurs. 2017;35(4):178-86. https://doi.org/10.1016/j.jvn.2017.08.001

21. Wu M, Pan H, Leng W, Lei X, Chen Liu, Liang Z, et al. Distribution of microbes and drug susceptibility in patients with diabetic foot infections in Southwest China. J Diabetes Res. 2018;1-9. https://doi.org/10.1155/2018/9817308

22. Noor S, Raghav A, Parwez I, Ozair M, Ahmad J. Molecular and culture based assessment of bacterial pathogens in subjects with diabetic foot ulcer. Diabetes Metabol Syndr: Clin Res Rev. 2018:1-5. https://doi.org/10.1016/j.dsx.2018.03.001

23. Pugazhendhi S, Dorairaj AP. Appraisal of biofilm formation in diabetic foot infections by comparing phenotypic methods with the ultrastructural analysis. J Foot Ankle Surg. 2018,57:309-315. https://doi.org/10.1053/j.jfas.2017.10.010

24. Sonal SM, Rodrigues GS, Vyasc N, Mukhopadhyay C. Antimicrobial susceptibility pattern of aerobes in diabetic foot ulcers in a South-Indian tertiary care hospital. Foot. 2018;37:95-100. https://doi.org/10.1016/j.foot.2018.07.002

25. Martínez-Gomes DA, Ramírez-Almagro C, Campillo-Soto A, Morales-Cuenca G, Pagán-Ortiz J, Aguayo-Albasini JL. Infecciones del pie diabético: prevalencia de los distintos microorganismos y sensibilidad a los antimicrobianos. Enfermed Infec Microbiol Clín. 2009;27(6):31721. https://doi.org/10.1016/j.eimc.2008.07.004

26. Martins MA, Santos SLV, Leão LSNO, Araujo NP, Bachion MM. Prevalence of resistance phenotypes in Staphylococcus aureus and coagulasenegative isolates of venous ulcers of primary healthcare patients. Rev Soc Bras Med Trop. 2012,45(6):717-22. https://doi.org/10.1590/ S0037-86822012000600012

27. Santos SLV, Martins MA, Vasconcelos LSNOL, Lima ABM, Malaquias SG, Bachion MM. Bastonetes Gram-negativos em úlceras venosas e implicações para o atendimento de enfermagem na atenção primária. Rev Eletr Enf. 2014;(16):2. https://doi.org/10.5216/ree.v16i2.24670 
28. Perim MC, Borges JC, Celeste SRC, Orsolin EF, Mendes RR, Mendes GO, et al. Aerobic bacterial profile and antibiotic resistance in patients with diabetic foot infections. Rev Soc Bras Med Trop. 2015;48(5):546-54. https://doi.org/10.1590/0037-8682-0146-2015

29. Balbuena JO, Madero RG, Gómez TS, Caballero MC, Romero IS, Martínez AR. Microbiología de las infecciones de úlceras por presión y de origen vascular. Rev Esp Geriatr Gerontol. 2015;50(1):5-8 https://doi.org/10.1016/j.regg.2014.08.001

30. Cardoso NA, Cisneiros LL, Machado CJ, Cenedezi JM, Procópio RJ, Navarro TP. Gênero bacteriano é fator de risco para amputação maior em pacientes com pé diabético. Rev Col Bras Cir. 2017;44(2):147-53. https://doi.org/10.1590/0100-69912017002007

31. Agwu E, Lhongbe J, Inyang N. Prevalence of Quinolone-susceptible Pseudomonas aeruginosa and Staphylococcus aureus in Delayedhealing DFU's in Ekpoma, Nigeria. Int Wound J. 2010;22(4):100-5. Available from: https://www.woundsresearch.com/content/ prevalence-quinolone-susceptible-pseudomonas-aeruginosa-and-staphylococcus-aureus-delayed-he

32. Xie X, Bao Y, Ni L, Liu D, NiuS, Lin H, et al. Bacterial profile and antibiotic resistance in patients with diabetic foot ulcer in Guangzhou, Southern China: focus on the differences among different Wagner's Grades, IDSA/IWGDF Grades, and Ulcer Types. Int J Endocrinol. 2017;(8694903):1-12. https://doi.org/10.1155/2017/8694903

33. Arjunan SP, Tint AN, Aliahmad B, Kumar DK, Shukla R, Miller J, et al. High-Resolution spectral analysis accurately identifies the bacterial signature in infected chronic foot ulcers in people with diabetes. SAGE. 2018;17(2):78 -86. https://doi.org/10.1177/1534734618785844

34. Ayed MYA, Ababneh M, Robert AA, Alzaid A, Ahmed RA, Salman A, et al. Common pathogens and antibiotic sensitivity profiles of infected diabetic foot ulcers in Saudi Arabia. Int J Lower Extrem Wounds. 2018;00(0):1-8. https://doi.org/10.1177/1534734618793557

35. Yildiz PA, Özdil T, Dizbay M, Tunçcan OG, Hizel K. Peripheral arterial disease increases the risk of multidrug-resistant bacteria and amputation in diabetic foot infections. Turk J Med Sci. 2018;48:845-50. https://doi.org/10.3906/sag-1803-217

36. Lázaro-Martínez JL, Álvaro-Afonso FJ, Sevillano-Fernández D, Molines-Barroso RJ, García-Álvarez Y, García-Morales E. Clinical and antimicrobial efficacy of a silver foam dressing with silicone adhesive in diabetic foot ulcers with mild infection. Int J Lower Extrem Wounds. 2019;18(3):269-78. https://doi.org/10.1177/1534734619866610

37. Dwedar R, Ismail DK, Abdulbaky A. Diabetic foot infection: microbiological causes with special reference to their antibiotic resistance pattern. Egypt J Med Microbiol. 2015;24(3):95-102

38. Akhi MT, Ghotaslou R, Asgharzadeh M, Varshochi M, Pirzadeh T, Memar MY, et al. Bacterial etiology and antibiotic susceptibility pattern of diabetic foot infections in Tabriz, Iran. GMS Hyg Infect Control. 2015;10:1-6. https://doi.org/10.3205/dgkh000245

39. Kurup R, Ansari AA. A study to identify bacteriological profile and other risk factors among diabetic and non-diabetic foot ulcer patients in a Guyanese hospital setting. Diabetes Metabol Syndr: Clin Res Rev. 2019;13(3):1871-6. https://doi.org/10.1016/j.dsx.2019.04.024

40. Zubair $\mathrm{M}$, Ahmad J. Potential risk factors and outcomes of infection with multidrug resistance among diabetic patients having ulcers: 7 years study. Diabetes Metabol Syndr: Clin Res Rev. 2019;13(1):414-8. https://doi.org/10.1016/j.dsx.2018.10.014

41. Yang H, Wang WS, Tan Y, Zhang DJ, Wu JJ, Lei X. Investigation and analysis of the characteristics and drug sensitivity of bacteria in skin ulcer infections. Chinese J Traumatol. 2017;20:194-7. https://doi.org/10.1016/j.cjtee.2016.09.005

42. Agência Nacional de Vigilância Sanitária (Anvisa). Plano Nacional para a Prevenção e o Controle da Resistência Microbiana nos Serviços de Saúde. Anvisa; 2017. 84p.

43. Borges EL, Frison SS, Sampaio KH, Guedes ACM, Lima VLAN, Oliveira OMM, et al. Effect of polyhexamethylene biguanide solution on bacterial load and biofilm in venous leg ulcers. J Wound Ostomy Continence Nurs. 2018;45(5):425-31. https://doi.org/10.1097/WON.0000000000000455

44. Agência Nacional de Vigilância Sanitária (Anvisa). Série Segurança do Paciente e Qualidade em Serviços de Saúde. Gerência de Vigilância e Monitoramento em Serviços de Saúde (GVIMS) Gerência Geral de Tecnologia em Serviços de Saúde (GGTES). Critérios diagnósticos das infecções relacionadas ao cuidar em saúde. Anvisa, 2017. 86p.

45. Wound Ostomy and Continence Nurses Society (WOCN). Clean vs. sterile dressing techniques for management of chronic wounds: a fact sheet. J Wound Ostomy Continence Nurs. 2012;39(2S):S30-S34. https://doi.org/10.1097/WON.0b013e3182478e06

46. Sibbald RG, Woo K, Ayello E. Increased bacterial burden and infection: nerds and stones. Clin Res Audit [Internet]. 2007[cited 2019 Dec 2];3(2):25-46. Available from: https://www.woundsinternational.com/uploads/resources/content_9132.pdf

47. Menoita E, Seara A, Santos V. Plano de Tratamento dirigido aos sinais clínicos da infecção da ferida. J Aging Inov. 2014;3(2):62-73.

48. National Pressure Ulcer Advisory Panel, European Pressure Ulcer Advisory Panel and Pan Pacific Pressure Injury Alliance (NPUAP). Prevention and treatment of pressure ulcers: clinical practice guideline. Emily Haesler (Ed.). Cambridge Media: Osborne Park, Western Australia; 2014. 348p.

49. Stallard Y. When and how to perform cultures on chronic wounds? J Wound Ostomy Continence Nurs. 2018;45(2):179-86. https://doi. org/10.1097/WON.0000000000000414

50. Vieira CPB, Araújo TME. Prevalência e fatores associados a feridas crônicas em idosos na atenção básica. Rev Esc Enferm USP. 2018;52:e03415. https://doi.org/10.1590/S1980-220X2017051303415 